\title{
The John G. White Collection at the Cleveland Public Library
}

\section{$A$ description of a notable accumulation of folklore and Orientalia prepared by its librarian.}

$\mathrm{P}$ UBLIC LIBRARIES have not always conceived of their task as including the building up of great scholarly collections or, if they have thought of it, have not often had the wherewithal to do so. In this country the municipal libraries of Boston and New York, with their noted specialties, have not had many imitators in the public library field. The chief, perhaps, are Detroit's Burton collection of American history and Cleveland's White collectionboth originating in private generosity.

In 1899 Cleveland had an experience unfortunately not without precedent in American library history. Its revenue was sharply reduced to help out other city departments whose payrolls were more intimately connected with votes. John G. White, a lawyer who had been president of the library board and was to be again, resented this action of the city government. He determined to compensate the library in some degree by adding to the book collection items which probably otherwise could not be acquired. Burton's translation of the Arabian Nights was the first item given, followed by Payne's. Stemming from these two versions came other collections of folk tales and other translations of Oriental literature. Before long, the late William $\mathrm{H}$. Brett, then chief librarian, realizing that a major gift was under way, segregated the books as a special White collection. Eventually this received a head, its own room, and its own catalog.

Mr. White's gifts continued throughout his life, which had more than thirty years to run. His procedure was to receive the books at his office, examine them hastily or in detail, and when they became too numerous, send them to the library for collation and storage.

Mr. White was a bachelor lawyer whose father had been clerk of the Federal District Court. He became particularly noted for his knowledge of real estate and municipal law and in his latter years was recognized as dean of the Cleveland bar. As a testament to his legal learning, the saying was that one need merely enter a courtroom and see the huge piles of books representing authorities cited, to know that John G. White was trying a case.

Mr. White's hobbies were fishing, mushroom hunting, blood and thunder yarns, the collecting of chess books, and the library. He was president of the board when William $\mathrm{H}$. Brett was appointed librarian in I 884 and when Linda A. Eastman succeeded him in 1918. His was no mere honorary position. He was constantly available for advice, always shrewd, always foresighted. Any history of the Cleveland Public Library must rank him with Mr. Brett and Miss Eastman as a most potent factor in the making of the library. Just before his death 
in 1928 , at the age of 83 , he witnessed the first operation of a sound and liberal staff pension system, drafted chiefly by him. At his death he bequeathed to the library his unrivaled collection of chess and checker books, together with his estate, which was to continue his gifts in all fields. Book purchases and binding come out of the White funds, but not staff salaries or other expenses, which are borne by the library.

The White collection, now housed in a handsome room overlooking Lake Erie, on the third floor of the main library building, is open weekdays from 9 A.M. until 6 P.M. Books are lent with considerable freedom to local readers and also to other libraries, with which a thriving trade is carried on. The war has naturally seen increased call for Oriental books, especially language treatises.

The library gets considerable publicity out of the collection. Americans, it seems, are always interested to learn that something ultramodern, like food rationing, the bazooka, or Frank Sinatra, is paralleled in China or ancient Egypt. Such discoveries always find space, with incidental mention of the library, even in today's crowded pages.

The present policy of bookbuying considers the collection as one primarily for the scholar or reference worker. Its many rarities have been bought to anticipate or meet the inquirer's even occasional need. In certain fields, however, the book collector's pattern has been followed and an effort made to buy every issue of every edition. Examples are chess and checkers, Robin Hood and the Rubáiyát.

The folklore books are of first importance. Inferior to Harvard's enormous material on English ballads gathered by Child and Kittredge and making no attempt at more than a representative gathering on alchemy, astrology, witchcraft, and magic, the collection has perhaps the country's largest group of books on proverbs and a wide range of material on all fields of folklore, particularly German. Much attention has been paid in late years to acquiring romances, both the medieval and the later chivalric, and the accumulation is important. Some handsomely bound sixteenth-century Italian translations of Perceforest and of Palmerin of England bear the arms of J. A. de Thou.

Folklore and romances have led to the acquisition of medieval literature. Middle English, and even more, Old French and Provençal, Middle High German, Middle Dutch, and Old Norse are strongly represented. Some effort has been made to collect early Russian literature.

Catalogs of medieval and Oriental manuscripts were originally procured by $\mathrm{Mr}$. White as guides to unpublished chess material which might be copied or reproduced. They have since been purchased systematically and are already numerous enough to have been helpful to many libraries.

\section{Chapbooks}

In the history of the book trade and the transmission of popular literature, the chapbook has played an important part. Of English chapbooks there is but a fair accumulation, over eight hundred. Few of these are American. There is also a fair assortment of English broadsides and street slip ballads. Foreign chapbooks make a strong showing. There are over 300 French, 100 German, 30 Dutch, 220 Italian, 60 Portuguese, and roo Spanish ones, with a few in other languages.

Gypsies are represented extensively. Notable features are several volumes of scrapbooks on the gypsies of Great Britain in the early part of the century, compiled by W. Towneley Searle, sometime secretary of the Gypsy Lore Society; and WattsDunton's copy, with notes and clippings inserted by him, of Lavengro.

The second great division of the White 
collection, folklore being the first, is Orientalia. The Orient may have appealed to Mr. White because of his interest in the Oriental game of chess or because of its glamorous associations. Either inducement was strengthened in 1899 , the year in which his gifts began, by the American acquisition of the Philippines. As Mr. White used to point out, this marked a new era for the United States. For the first time we were brought face to face with an Oriental people and with the problem of governing them. We knew almost nothing of their past, their literature, their traditions, or their ways of thought. The success of the British and the Dutch in ruling Eastern peoples was due largely to the patient work of scholars who had investigated every aspect of the life of the subject races. In line with this, the White collection was designed to be a national headquarters for Oriental information. Particularly did Mr. White wish the Oriental to interpret himself directly rather than through secondary material. Comprehensive collections of Oriental literature, in text and in translation, therefore, were acquired.

The Orient is so large a field that it has been necessary to limit purchases to the period before European penetration. India is an exception, for reasons stated later.

Oriental texts are bought as liberally as possible. Except for Chinese and Japanese, the material is largely in Western editions, not many Far Eastern imprints having been acquired. Periodicals have been particularly sought. Of forty-eight less well-known journals the first edition of the Union List of Serials showed that the White collection had as many as Harvard, Yale, Wisconsin, the New York Public Library, and the Library of Congress together. Though the second edition of the serial list might qualify this showing, it would still leave the White collection in a strong position.

As for individual topics, and without im- plying invidious comparisons with other libraries, a count based on Emeneau's Union List of Printed Indic Texts and Translations in American Libraries indicated that in I935 the White collection had roughly 2400 volumes in Sanskrit, Pali, and Prakrit literature. Harvard had I900, and Chicago, Yale, Columbia, and the Library of Congress followed with lesser numbers.

Emeneau's list suggests a like superiority for India's modern literature, except for such libraries as the Justin E. Abbott Marathi books in Columbia. Sinhalese is particularly strong, the basis being a group of 250 pamphlets, mostly in verse, formerly owned by Ananda K. Coomaraswamy. From Sir George A: Grierson's library came a group of thirty Hindustani chapbooks. There are seventy books in Kanarese.

\section{Arabic Collection}

The Arabic collection is large. Only classical Arabic is sought; present-day texts may be found in the library's foreign division. It is thought that nearly all the important classical authors are to be found here. There are thirty-eight texts of romances of the Bani Hilal cycle.

The most important features in Arabic are the Koran and the Arabian Nights. Of. the Koran there are versions in thirty-eight languages, perhaps the widest variety that has been brought together, including Georgian, Javanese, and Swahili. Among them are the 1543 edition of the dialogue of Mohammed and the Jew Abdias (containing the first attempt to translate any part of the Koran into a Western language) and a Chinese Moslem book of selections. with the Arabic in Chinese transliteration - a linguistic phenomenon indeed.

The Arabian Nights collection numbers about six hundred volumes, without attempting to gather children's editions, retellings of Lane, etc., in fifty-four languages. 
The British Museum Catalogue of Arabic Printed Books, with the supplement, records translations in only eighteen languages.

The Persian collection is also important, having some unpublished historical manuscripts of the first rank. The rarest book is perhaps the handsome edition of the poems of Sultan Selim the Grim, issued for Sultan Abdul Hamid by Kaiser Wilhelm II.

The Rubaiiyát of Omar Khayyám is represented by some six hundred volumes, mostly from the library of the late Clarke W. Walton of Monroe, N.C. It is rich in privately printed and finely bound editions, to which the Rubáiyát naturally lends itself. As Potter's bibliography shows, the versions put out by private presses and amateur printers are so many that the most ambitious collector might well despair of attaining completeness, but more than a good beginning has been made here.

While all Oriental literary languages are represented by at least their chief works, two groups, not large numerically, may be singled out because they appear superior to those available elsewhere in the United States. These are Jagataic Turki and Burmese.

\section{India Material}

India material is comprehensive, particularly on archeology. Until recently, in accordance with the general principle adopted for the Orient, no attempt was made to gather material on the period since 1750. The acquisition of the Ernest Stutz collection of 234 manuscripts, aggregating nineteen thousand pages, covering British India from 1750 to 1850 , made it desirable to extend accordingly the date for book buying. The Stutz manuscripts include letters of George III, Wellington, Clive, the younger Pitt, Cornwallis, and Warren Hastings, with many letters by and to Dundas. There is an important group of books on French and Portuguese India.
On Madagascar most libraries have bought only incidentally. Some hasty comparisons suggest that our 350 volumes may be the largest group available in the country. Some manuscripts came with the Stutz collection. There is also important material, both manuscript and printed, on the neighboring islands of Mauritius and the Seychelles.

Oriental religions are well represented. Particularly notable are the collections on Zoroastrianism and Sikhism.

The cutting off of the European market has encouraged strengthening the collection's resources on Latin American archeology and folklore. This is in line with the library's new Latin American room, which houses several thousand volumes, including many long sets. The White collection's facsimiles of Mexican and Maya codices are impressive, including most of those issued in the last decade by the Mexican government in editions of twenty-five and thirty copies. Much material in Spanish remains to be gathered, but a few years should show a considerable difference.

Incunabula number only slightly over fifty, but it is to be considered that many of the White collection's subjects did not have books devoted to them in the fifteenth century. There are eight incunabula containing the Gesta Romanorum; unfortunately the first edition, printed at Cologne by Ulrich Zell about 1472 , was lost at sea in 1942.

\section{Manuscripts}

There are over 1250 manuscripts, those on chess and checkers predominating. Among them are some interesting medieval volumes: a fifteenth-century text of Gautier de Châtillon's Alexandreis; an unpublished compilation of saints' lives, written probably near Rheims or Soissons; a codex containing variants of Brut's Chronicle and of the Vindicta Salvatoris; and a miscellaneous 
volume, discussed by Eva M. Sanford in Speculum (12: 203-08). These last three are all of the fourteenth century.

Besides the Stutz manuscripts on India, already mentioned, the English manuscripts include Samuel Wilson's little-known account of his journey to Yemen in 1799; Frances Power Cobbe's unpublished "Lady's Ride through Palestine;" six volumes of notes for a history of chess by Sir Frederic Madden; two letters of Andrew Lang on phantoms; two manuscripts on the Druses; a Persian roadbook from the middle of the eighteenth century; "Who Was Who in the Story of Anthony Sherley," by the eminent Orientalist, Sir Edward D. Ross; and two volumes of reports and notes on Sierra Leone.

The Persian manuscripts have already been mentioned. There are also fourteen pictographic manuscripts of the Moso or Nashi, a non-Chinese tribe of Yunnan, and a "pustaka," or magical manual, written on birchbark and used by the Batak tribes of Sumatra.

\section{Chess and Checkers}

The chess and checker collection is the largest in the world, a fact attested, for example, by the preface to Harold J. R. Murray's standard History of Chess. Since then it has received large accretions by purchase from the English Rimington Wilson chess library, second only to Mr. White's, and from Dr. Albrecht Buschke, a dealer whose chess library was once considered the largest in Germany. The aim here is to buy every issue of every edition of all chess and checker books. Manuscripts in European and Oriental libraries have been copied or reproduced. Magazines of chess interest are bought and bound.
A comprehensive collection on chess may sound to the outsider much like a collection on algebra-to be respected, no doubt, but hardly interesting. This is not the case. Zest for the visitor who does not care greatly about chess comes when he sees the illustrative material, such as poetry, fiction, and general literature containing chess matter. Thus, there is an extensive Rabelais collection because of the much-discussed chess game in the fifth book. Of Castiglione's Book of the Courtier, the sixteenth-century Emily Post, there are fifty-seven editions printed in 1600 and before. Among other authors not ordinarily looked for in a chess library but extensively represented here are Benjamin Franklin (for his Morals of Chess), the Gesta Romanorum, and Polydore Virgil. Of the Russian translation of Franklin's "Morals" (St. Petersburg, I791) but two other copies have been reported: one owned by King Albert of Belgium and the other by Czar Nicholas II. The copy of the first edition of Through the Looking-Glass is an autographed presentation copy from Sir John Tenniel.

\section{Collection of Ninety Thousand}

All told, the White collection numbers about ninety thousand volumes, and additions come at the rate of two to three thousand annually. Supplementing it, there may be reckoned the more popular books on like subjects bought for the library's circulating department.

The collection is a monument to a public spirited citizen who, like too few of his kind, stepped out of the usual routine of enriching a university or a museum and remembered the service that could be rendered to the community by a public library. 